\title{
Rekomendasi Pembelian Barang Pada Sistem Retail Dengan Metode Dekomposisi Census II
}

\author{
Ellysa Tjandra \\ Program Studi Teknik Informatika \\ Universitas Surabaya \\ ellysa@staff.ubaya.ac.id
}

\author{
Susana Limanto \\ Program Studi Teknik Informatika \\ Universitas Surabaya \\ susana@staff.ubaya.ac.id
}

\author{
Arie Indrawan \\ Program Studi Teknik Informatika \\ Universitas Surabaya \\ s160415079@student.ubaya.ac.id
}

\begin{abstract}
Abstrak - Masalah ketersediaan stok masih menjadi salah satu hal penting dalam menjalankan bisnis di dunia perdagangan, khususnya bisnis retail. Ketersediaan stok berhubungan erat dengan keputusan pembelian barang yang dilakukan oleh toko. Jika keputusan dalam menentukan jumlah barang yang dibeli kurang tepat, maka bisa berakibat jumlah stok yang terlalu banyak (overestimate) atau terlalu sedikit (underestimate). Untuk mendukung keputusan penentuan jumlah barang yang dibeli, diperlukan suatu sistem yang dapat membantu menyediakan rekomendasi jumlah barang yang sebaiknya dibeli, berdasarkan data histori permintaan barang, stok gudang, serta stok pesanan ke pemasok maupun stok pesanan dari pelanggan. Studi kasus dalam penelitian ini adalah toko yang menjual air mineral kemasan galon dan gas tabung LPG. Untuk dapat memperkirakan jumlah permintaan barang diperlukan peramalan (forecasting) dengan metode tertentu, sehingga dapat dihasilkan peramalan permintaan barang yang mendekati kondisi riil. Pada penelitian ini, peramalan permintaan barang dilakukan dengan metode Dekomposisi Census II, di mana tingkat akurasi kesalahan dihitung menggunakan Mean Absolute Error (MAE). Metode Dekomposisi Census II digunakan dalam penelitian ini karena metode ini mampu memisahkan data dari unsur musiman, tren, siklus, dan random sehingga ketepatan hasil ramalan meningkat. Hasil uji coba menunjukkan bahwa MAE periode bulanan mempunyai nilai yang lebih kecil dibandingkan periode tahunan, sehingga diperoleh kesimpulan bahwa peramalan periode bulanan memiliki ketepatan yang lebih tinggi dibanding periode tahunan.
\end{abstract}

Kata Kunci: Dekomposisi Census II, Peramalan, Rekomendasi, Retail

\section{PENDAHULUAN}

Salah satu masalah yang ada dalam toko retail adalah keterbatasan tempat penyimpanan yang dimiliki. Untuk memenuhi semua permintaan yang ada, toko retail harus bisa mengatur stok barang yang ada di dalam toko, agar tidak menyimpan barang secara berlebihan dan juga tidak kekurangan stok barang jika ada permintaan dari pelanggan. Berdasarkan masalah tersebut, maka dibutuhkan suatu sistem yang dapat memperkirakan jumlah pembelian barang supaya toko dapat mengatur stok barang yang dapat disimpan di gudang, sehingga semua permintaan dapat terpenuhi dan tidak menyimpan stok yang berlebihan. Sistem perlu dilengkapi dengan fasilitas peramalan jumlah barang yang terjual di periode mendatang sebagai dasar bagi perusahaan untuk mengambil keputusan yang tepat mengenai jumlah barang yang perlu dipesan dari supplier. Hasil peramalan yang akurat dapat mempengaruhi kondisi perusahaan di masa mendatang [1]. Jumlah permintaan barang pada toko retail yang digunakan sebagai studi kasus penelitian ini tidak selalu sama di setiap periodenya dan terdapat peningkatan di waktu-waktu tertentu dan beberapa berulang setiap tahunnya. Hal ini menandakan bahwa permintaan pada toko ini dipengaruhi oleh unsur tren, musiman, siklus, dan random. Oleh karena itu dibutuhkan metode peramalan yang dapat memperhitungkan keempat faktor tersebut sehingga dapat meningkatkan ketepatan hasil peramalan dan dapat diimplementasikan pada data runtut waktu atau time series. Metode peramalan yang dapat digunakan adalah metode peramalan Dekomposisi Census II. Metode ini dapat diterapkan pada data time series atau runtut waktu. Metode Dekomposisi Census II juga dapat memperhitungkan faktor tren, siklus, musiman, dan random [2].

Metode Dekomposisi Census II sudah banyak digunakan untuk melakukan peramalan di berbagai bidang. Olvi dalam salah satu penelitiannya menggunakan metode ini untuk meramalkan jumlah pengunjung perpustakaan Universitas Sam Ratulangi Manado [3]. Penelitian tersebut dilakukan untuk mengetahui tingkat kemanfaatan perpustakaan yang ada. Hasil yang didapat akan digunakan sebagai bahan penelitian lanjutan untuk perencanaan perbaikan dan pengembangan fasilitas perpustakaan yang masih kurang [3]. Metode Dekomposisi Census II juga digunakan oleh Sujantri untuk meramalkan kebutuhan energi jual pada PT Perusahaan Listrik Negara (PLN) Cabang Bukittinggi. Penelitian yang dilakukan Sujantri bertujuan untuk meningkatkan pelayanan distribusi listrik di seluruh wilayah cakupan PLN Bukittinggi sehingga dapat mengurangi frekuensi pemadaman bergilir [4]. Selain itu, metode Dekomposisi Census II juga digunakan oleh Ketut dalam penelitiannya untuk meramalkan harga beras pada tingkat grosir [5]. 


\section{METODE DEKOMPOSISI CENCUS II}

Dalam melakukan peramalan, metode dekomposisi merupakan salah satu teknik yang dilakukan dengan pendekatan analisis data yang bersifat time series. Cara kerja metode ini adalah dengan memecah data menjadi beberapa bagian agar pola data terlihat sehingga dapat meningkatkan ketepatan hasil peramalan [3]. Ada empat macam pola data yang dapat dipisahkan melalui metode Dekomposisi Census II, yaitu musiman, tren, siklus, dan random. Persamaan dasar dari metode dekomposisi dapat dilihat pada Persamaan $1[6]$.

Data $=$ Pola $($ Tren, Siklus, Musiman $)+$ random

Ada beberapa tahapan yang harus dilakukan dalam menerapkan metode Dekomposisi Census II. Tahapantahapan tersebut meliputi:

\section{A. Penyesuaian Musiman Awal}

Pada tahap ini dilakukan pemisahan unsur musiman awal dengan unsur tren-siklus dan unsur random. Tahap ini terdiri dari beberapa langkah, yaitu:

1. Moving Average/Rata-Rata Bergerak Ganda Terpusat (MA 2x12)

Perhitungan rata-rata bergerak ganda dilakukan untuk memisahkan unsur musiman dan random dari data. Penghitungan rata-rata bergerak ganda yang digunakan adalah perhitungan rata-rata bergerak ganda terpusat 12 bulanan (MA 2x12). Data MA 2x12 diletakan mulai bulan ke 7 , sehingga data 6 bulan pertama dan 6 bulan terakhir hilang. Persamaan dari MA 2x12 dapat dilihat pada Persamaan 2.

$$
M_{t}=T_{t} * C_{t}
$$

di mana:

$M_{t}=$ Rata - rata bergerak periode $\mathrm{t}$

$T_{t} \quad=$ Gerakan tren jangka panjang pada periode $\mathrm{t}$.

$C_{t} \quad=$ Faktor siklus pada periode $\mathrm{t}$.

2. Rasio Terpusat

Rasio terpusat dicari dengan membagi data asli dengan hasil perhitungan dari MA 2x12. Hasil pembagian diletakkan mulai bulan ke 7. Persamaan dari Rasio terpusat dapat dilihat pada persamaan 3 .

$$
\frac{X_{t}}{M_{t}}=R_{t}=\frac{I_{t} * T_{t} * C_{t} * E_{t}}{T_{t} * C_{t}}=I_{t} * E_{t}
$$

di mana:

$R_{t} \quad=$ Rasio periode $\mathrm{t}$

$X_{t} \quad=$ Nilai data aktual deret waktu pada periode $\mathrm{t}$

$I_{t} \quad=$ Faktor musiman pada periode $\mathrm{t}$

$E_{t} \quad=$ komponen acak/error pada periode $\mathrm{t}$

3. Faktor Penyesuaian Musiman Awal
Tahap ini digunakan untuk menghilangkan nilai ekstrim dengan cara menghitung rata-rata bergerak $3 \times 3$ bulan (MA 3x3). Perhitungan MA 3x3 akan menyebabkan 2 data di akhir dan di awal hilang. Untuk mengganti nilai yang hilang dilakukan perhitungan rata-rata dari dua nilai yang mengikutinya.

4. Standar Deviasi

Langkah keempat adalah menghitung standar deviasi. Standar deviasi dihitung dengan cara mengkuadratkan selisih antara MA 3x3 dengan rasio terpusat. Standar deviasi digunakan sebagai batas antara nilai normal dengan nilai ekstrim. Batas yang diterapkan biasanya plus atau minus 2 standar deviasi. Apabila didapati adanya nilai ekstrim, maka nilai ekstrim ini diganti dengan rata-rata dari periode sebelumnya dengan periode berikutnya. Selanjutnya dilakukan perhitungan rata-rata standar deviasi dari setiap bulan pada beberapa periode.

5. Penyesuaian Rasio 1200

Pada langkah ini dilakukan penyesuaian sehingga jumlahnya menjadi 1200. Penyesuaian dilakukan dengan cara membagi hasil observasi dengan rata-rata nilai ekstrim per periode dan mengalikannya dengan 100\%. Hasil pembagian setiap periodenya kemudian dijumlahkan sehingga didapatkan hasilnya adalah 1200 .

6. Faktor Musiman Awal

Proses mencari faktor musiman awal dilakukan dengan cara menghitung MA 3x3 dari setiap bulan. Selanjutnya dicari rata-rata dari MA $3 \times 3$, hasilnya disebut ramalan musiman satu tahun ke depan.

7. Deret Data Penyesuaian Musiman Awal

Proses pencarian deret data penyesuaian musiman awal dilakukan dengan cara membagi data asli dengan faktor musiman awal lalu dikalikan dengan $100 \%$.

\section{B. Penyesuaian Musiman Akhir}

Tahap kedua dari metode Dekomposisi Census II adalah melakukan penyesuaian musiman akhir. Tujuan dari penyesuaian musiman akhir adalah menghilangkan pengaruh musiman dan unsur random yang tidak terdeteksi pada tahap sebelumnya. Langkah-langkah yang dilakukan dalam tahap kedua sama dengan tahap pertama kecuali langkah pertama. Pada tahap kedua, langkah pertama yang dilakukan adalah mengisolasi unsur tren-siklus dengan cara melakukan MA 15 Spencer dan Henderson. Persamaan MA 15 Spencer dan Henderson dapat dilihat pada Persamaan 4 dan rumus dari rasio musiman random akhir dapat dilihat pada Persamaan 5.

$$
\begin{aligned}
& M_{t}^{\prime}=T_{t}^{*} C_{t} \\
& F I E_{t}=\frac{X_{t}}{M_{t}}=\frac{I_{t} * T_{t} * C_{t} * E_{t}}{T_{t} * C_{t}}=I_{t} * E_{t}
\end{aligned}
$$

di mana:

$$
\begin{aligned}
& M_{t}^{\prime}=\text { MA } 15 \text { Spencer } \\
& F I E_{t} \quad=\text { Rasio musiman random akhir }
\end{aligned}
$$


MA 15 Spencer menyebabkan 7 nilai pada deret awal dan akhir data hilang. Tujuh nilai yang hilang di awal diprediksi dengan cara menghitung rata-rata 4 nilai observasi dari deret data hasil penyesuaian musiman awal sesudahnya. Sedangkan 7 nilai yang hilang di akhir dapat diprediksi dengan cara menghitung rata-rata 4 nilai observasi dari deret data penyesuaian musiman awal sebelumnya. Setelah semua data lengkap, selanjutnya dilakukan perkalian antara data yang ada dengan bobot masing-masing. Kelimabelas bobot yang digunakan adalah $-0,009,-0,019,-0,016,0,009,0,066$, $0,144,0,209,0,231,0,209,0,144,0,066,0,009,-0,016$, 0,019 , dan $-0,009$.

\section{Taksiran Nilai Tren-Siklus dan Nilai Random}

Hasil dari penyesuaian musiman akhir digunakan untuk menghitung nilai akhir taksiran unsur tren-siklus dan nilai akhir taksiran unsur random. Nilai akhir taksiran unsur trensiklus dilakukan dengan menggunakan MA 15 Spencer dan Henderson. Sedangkan nilai akhir taksiran unsur random diperoleh dengan cara membagi data asli dengan nilai akhir taksiran unsur tren-siklus yang sudah diperoleh sebelumnya. Hasil dari langkah ini adalah nilai dari setiap unsur yang ada, yakni: unsur musiman, tren-siklus dan random.

\section{Peramalan}

Peramalan dilakukan dengan cara mengalikan MA $3 \times 3$ terhadap data taksiran tren-siklus dengan nilai ramalan musiman satu tahun ke depan. Nilai ramalan musiman satu tahun ke depan dihitung bedasarkan rata-rata per bulan MA $3 \times 3$ pada faktor musiman akhir yang sebelumnya telah diperoleh

\section{HASIL DAN PEMBAHASAN}

\section{Analisis Metode}

Sistem peramalan yang dibuat menggunakan metode peramalan Dekomposisi Census II, karena data penjualan dari toko retail yang digunakan sebagai studi kasus penelitian ini merupakan data deret waktu. Data penjualan pada waktu-waktu tertentu, seperti menjelang akhir tahun dan hari raya Idul Fitri mengalami kenaikan. Hal ini dikarenakan pada saat akhir tahun ataupun hari raya Idul Fitri tidak ada pengiriman barang dari pabrik sehingga menjelang hari-hari tersebut banyak orang yang membeli dalam jumlah lebih banyak dari biasanya. Kejadian ini menunjukkan adanya unsur musiman. Selain itu adanya peralihan dari penggunaan air sumur atau Perusahaan Daerah Air Minum (PDAM) ke air mineral kemasan menyebabkan penjualan air mineral kemasan mengalami tren peningkatan. Metode Dekomposisi Census II merupakan metode yang memperhitungkan empat komponen pola data yaitu pola musiman, siklus, tren, dan error. Pemecahan data dilakukan untuk mengetahui komponen pola data dan perilaku data deret waktu yang dapat meningkatkan ketelitian dan akurasi hasil peramalan [6]. Jadi metode Dekomposisi Census II cocok untuk digunakan dalam penelitian ini.
Pemecahan dan penyesuaian untuk menghilangkan unsur komponen random serta mengidentifikasi komponen lainnya dilakukan dengan perhitungan Moving Average (MA). Faktor penting dalam metode Dekomposisi adalah penentuan panjang rata-rata bergerak/Moving Average (MA) yang tepat [6]. Jika jumlah suku dalam MA semakin besar maka kemungkinan unsur random yang dihilangkan akan semakin besar. Akan tetapi jika suku dalam MA semakin besar, maka data di awal dan akhir yang hilang akibat proses MA tersebut juga semakin banyak.

Untuk mengatasi hilangnya data yang cukup banyak, dapat digunakan jumlah suku yang lebih pendek meskipun tidak menghilangkan unsur random secara sempurna [6]. Metode Dekomposisi Census II menggunakan beberapa perhitungan MA. Panjang suku dalam MA dapat diubah berdasarkan hasil perhitungan ukuran akurasi kesalahan menggunakan Mean Absolute Error (MAE). Jika kesalahan peramalan yang dihasilkan semakin kecil, maka hasil dari peramalan semakin mendekati data asli atau keadaan nyata [7]. Sebelum implementasi metode Dekomposisi Census II ke dalam sistem peramalan penjualan pada toko retail " $X$ ", dilakukan analisis terhadap perhitungan proses penentuan faktor penyesuaian musiman awal dan akhir. Dalam proses penentuan faktor penyesuaian musiman awal dan akhir berdasarkan teori dilakukan perhitungan menggunakan MA $3 \times 3$ dan MA 3x3. Akan tetapi dalam penelitian ini dilakukan analisa menggunakan kombinasi dengan MA $5 \times 5$. Jadi terdapat 4 kombinasi untuk menganalisa MA yang cocok yang dapat ditunjukkan dengan nilai MAE yang terkecil. Empat kombinasi tersebut adalah MA 3x3 dengan MA 3x3, $3 \times 3$ dengan MA $5 \times 5$, $5 \times 5$ dengan $3 \times 3$, dan $5 \times 5$ dengan $5 \times 5$. Data penjualan pada toko retail " $X$ " yang digunakan untuk analisa adalah data penjualan produk Aqua Galon 19L dari tahun 2010 sampai 2017. Dari data penjualan tersebut dilakukan perhitungan untuk mencari nilai peramalan penjualan produk Aqua Galon 19L pada periode 2017. Hasil peramalan dievaluasi dengan menggunakan MAE. MAE hasil peramalan dengan 4 macam kombinasi perhitungan faktor penyesuaian musiman awal dan akhir dapat dilihat pada Tabel 1 .

Tabel 1. MAE Hasil Peramalan Aqua Galon 19L

\begin{tabular}{llr}
\hline $\begin{array}{l}\text { Metode Perhitungan } \\
\text { Faktor Penyesuaian } \\
\text { Musiman Awal }\end{array}$ & $\begin{array}{l}\text { Metode Perhitungan } \\
\text { Faktor Penyesuaian } \\
\text { Musiman Akhir }\end{array}$ & MAE \\
\hline MA 3x3 & MA 3x3 & 14,75 \\
\hline MA 3x3 & MA 5x5 & 14 \\
\hline MA 5x5 & MA 3x3 & 12,83 \\
\hline MA 5x5 & MA 5x5 & 16,58 \\
\hline
\end{tabular}

Tabel 1 menunjukkan bahwa hasil peramalan dengan menggunakan kombinasi MA $5 \times 5$ dan MA $3 \times 3$ dalam perhitungan faktor penyesuaian musiman awal dan akhir memberikan hasil MAE paling kecil, yaitu 12,83. Oleh karena itu pada penelitian yang dibuat, perhitungan faktor penyesuaian musiman awal akan dilakukan dengan 
menggunakan MA $5 \times 5$ dan perhitungan faktor penyesuaian musiman akhir akan dilakukan dengan menggunakan MA $3 \times 3$.

\section{Desain Proses Peramalan}

Sistem peramalan dengan metode Dekomposisi Census II terdiri dari beberapa proses. Rangkaian proses diawali dengan proses pemilihan data penjualan produk. Setelah produk dipilih, maka selanjutnya melakukan perhitungan menggunakan metode Dekomposisi Census II. Proses perhitungan diawali dengan menghitung penyesuaian musiman awal. Proses penyesuaian musiman awal diawali dengan melakukan Moving Average (MA) 2x12. Selanjutnya adalah menghitung rasio terpusat dengan cara membagi data asli dengan data hasil MA $2 \times 2$. Selanjutnya adalah proses penggantian nilai ekstrim yang terdapat dalam data. Penggantian nilai ekstrim diawali dengan proses menghitung MA 3x3 dari data hasil rasio terpusat. Selanjutnya adalah menghitung standar deviasi dan menentukan batas atas dan bawah untuk menentukan nilai ekstrim.

Batas atas dapat dicari dengan menambah hasil MA 3x3 dengan 2 kali standar deviasi, sedangkan batas bawah dapat dicari dengan mengurangi hasil MA 3x3 dengan 2 kali standar deviasi. Jika terdapat nilai ekstrim yang dilihat dari apakah nilai tersebut di luar batas yang sudah dihitung, maka dilakukan penggantian nilai tersebut. Jika tidak ada maka tidak perlu dilakukan penggantian nilai dari data rasio terpusat. Selanjutnya dilakukan perhitungan faktor musiman awal, yang diawali dengan melakukan taksiran nilai yang hilang akibat perhitungan MA. Langkah berikutnya adalah menghitung penyesuaian rasio 1200 dan dilanjutkan menghitung MA 5x5. Hasil dari perhitungan MA 5x5 adalah faktor penyesuaian musiman awal. Langkah selanjutnya adalah mencari deret data penyesuaian awal dengan cara membagi data asli dengan faktor penyesuaian musiman awal. Deret data penyesuaian musiman awal merupakan hasil akhir dari proses penyesuaian musiman awal.

Setelah proses penyesuaian awal sudah dilakukan, selanjutnya melakukan penyesuaian musiman akhir. Proses penyesuaian musiman akhir memiliki rangkaian proses yang sama dengan penyesuaian musiman awal, akan tetapi terdapat perbedaan pada tahap pertama yaitu MA 2x12 yang dilakukan pada penyesuaian musiman awal. Pada penyesuaian musim akhir, langkah ini diganti menjadi Moving Average/Rata-Rata bergerak berbobot 15 bulanan dari Spencer. Langkah selanjutnya sama seperti pada proses penyesuaian awal hingga memperoleh hasil deret data penyesuaian akhir. Setelah proses penyesuaian musiman awal dan penyesuaian musiman akhir sudah dilakukan, maka selanjutnya adalah mencari taksiran komponen tren-siklus dan random. Untuk mencari taksiran komponen tren-siklus digunakan MA 15 bulanan dari Spencer terhadap data deret penyesuaian musiman akhir. Taksiran komponen random dapat dicari dengan membagi deret data penyesuaian akhir dengan data taksiran komponen tren-siklus.

Proses terakhir dari peramalan ini adalah mencari nilai peramalan dan menghitung rekomendasi pembelian produk. Nilai peramalan dapat dicari dengan mengalikan ramalan tren setiap bulan dengan faktor ramalan musiman satu tahun kedepan. Ramalan tren dapat dicari menggunakan nilai kuadrat terkecil. Setelah hasil ramalan periode ke depan didapatkan maka langkah selanjutnya adalah menghitung rekomendasi pembelian produk. Rekomendasi pembelian produk dihitung dari hasil peramalan yang dikurangi dengan stok total yang ada pada toko retail "X". Hasil tersebut merupakan rekomendasi jumlah pembelian produk pada toko retail "X" dan sekaligus mengakhiri proses peramalan pada sistem peramalan ini. Desain flowchart proses peramalan menggunakan metode Decomposisi Census II dapat dilihat pada Gambar 1.

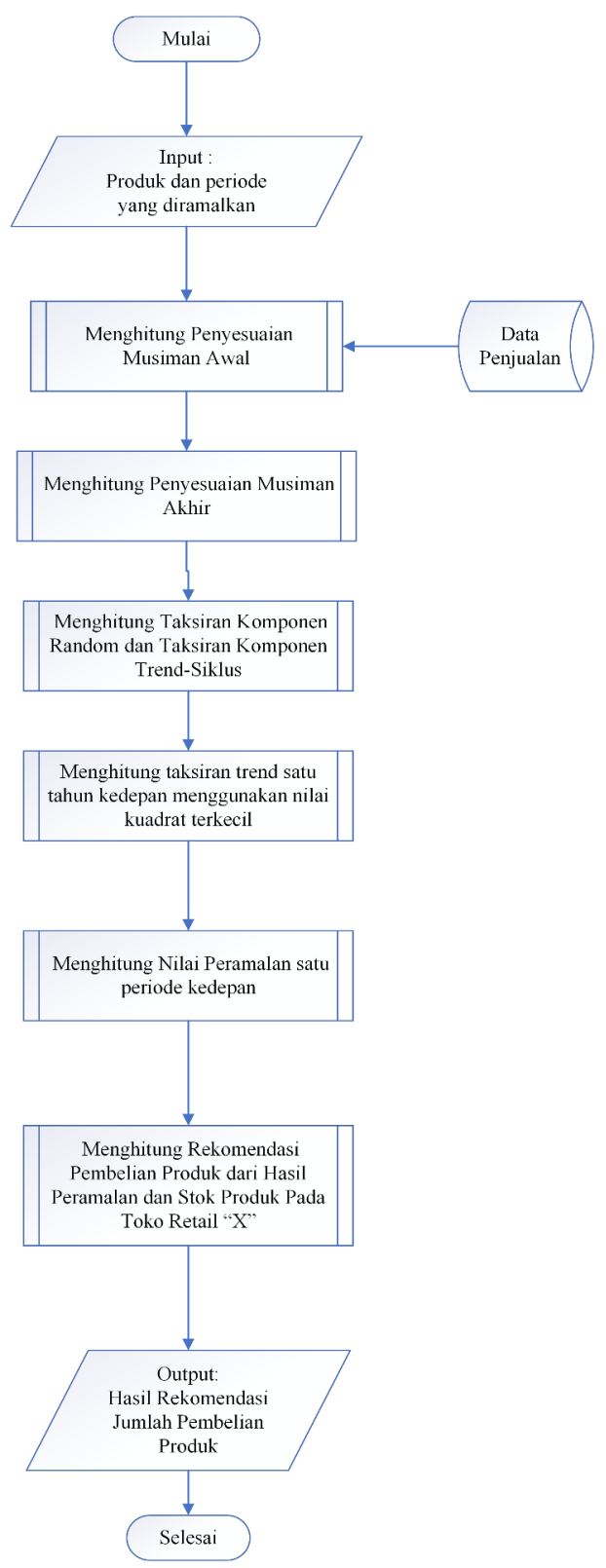

Gambar 1. Flowchart Proses Peramalan Keseluruhan

Untuk mengetahui tingkat akurasi hasil peramalan dengan metode Dekomposisi Census II, maka dilakukan perbandingan hasil peramalan dengan data penjualan riil. 
Data yang digunakan untuk uji coba adalah data penjualan produk Aqua Galon 19L dari tahun 2010 hingga tahun 2017. Data ini digunakan untuk meramalkan jumlah penjualan Aqua Galon 19L tahun 2013 hingga 2018. Hasil perhitungan peramalan Aqua Galon 19 liter pada tahun 2013 hingga Oktober 2018 dapat dilihat pada Tabel 2 sampai Tabel 7, sedangkan tingkat akurasi peramalan dapat dilihat pada Tabel 8. Tabel 2 sampai Tabel 7 menunjukkan bahwa peramalan periode bulanan tahun 2013, 2014, 2016, dan 2018 memberikan MAE lebih kecil dibandingkan peramalan periode tahunan.

Tabel 2. Hasil Peramalan dan MAE Aqua Galon 19 liter Tahun 2013

\begin{tabular}{lrrrrr}
\hline \multicolumn{1}{c}{ Bulan } & $\begin{array}{c}\text { Data } \\
\text { Aktual }\end{array}$ & \multicolumn{2}{c}{$\begin{array}{c}\text { Ramalan } \\
\text { Tahunan }\end{array}$} & \multicolumn{2}{c}{$\begin{array}{c}\text { Ramalan } \\
\text { Bulanan }\end{array}$} \\
\cline { 3 - 6 } & & $\begin{array}{c}\text { Hasil } \\
\text { Akurasi } \\
\text { (\%) }\end{array}$ & Hasil & $\begin{array}{c}\text { Akurasi } \\
\text { (\%) }\end{array}$ \\
\hline Januari & 990 & 1050 & 93,9 & 993 & 99,7 \\
\hline Februari & 1015 & 1068 & 94,8 & 902 & 88,9 \\
\hline Maret & 1016 & 1093 & 92,4 & 998 & 98,2 \\
\hline April & 1024 & 1144 & 88,3 & 969 & 94,6 \\
\hline Mei & 1020 & 1147 & 87,5 & 1011 & 99,1 \\
\hline Juni & 1027 & 1205 & 82,7 & 990 & 96,4 \\
\hline Juli & 935 & 1232 & 68,2 & 1033 & 89,5 \\
\hline Agustus & 976 & 1149 & 82,3 & 1020 & 95,5 \\
\hline September & 1022 & 1174 & 85,1 & 979 & 95,8 \\
\hline Oktober & 1056 & 1189 & 87,4 & 1011 & 95,7 \\
\hline November & 1015 & 1207 & 81,1 & 995 & 98,0 \\
\hline Desember & 1165 & 1236 & 93,9 & 1024 & 87,9 \\
\hline Hasil MAE & & & $\mathbf{1 3 6 , 1}$ & & $\mathbf{5 2 , 2}$ \\
\hline
\end{tabular}

Tabel 3. Hasil Peramalan dan MAE Aqua Galon 19 liter Tahun 2014

\begin{tabular}{lccccc}
\hline Bulan & $\begin{array}{c}\text { Data } \\
\text { Aktual }\end{array}$ & \multicolumn{2}{c}{$\begin{array}{c}\text { Ramalan } \\
\text { Tahunan }\end{array}$} & \multicolumn{2}{c}{$\begin{array}{c}\text { Ramalan } \\
\text { Bulanan }\end{array}$} \\
\cline { 3 - 6 } & & Hasil & $\begin{array}{c}\text { Akurasi } \\
(\%)\end{array}$ & $\begin{array}{c}\text { Hasil } \\
\text { Akurasi } \\
(\%)\end{array}$ \\
\hline Januari & 1145 & 1137 & 99,3 & 1071 & 93,5 \\
\hline Februari & 1202 & 1152 & 95,8 & 998 & 83,0 \\
\hline Maret & 1211 & 1141 & 94,2 & 1159 & 95,7 \\
\hline April & 1249 & 1160 & 92,9 & 1163 & 93,1 \\
\hline Mei & 1254 & 1152 & 91,9 & 1258 & 99,7 \\
\hline Juni & 1286 & 1178 & 91,6 & 1257 & 97,7 \\
\hline Juli & 1262 & 1130 & 89,5 & 1337 & 94,1 \\
\hline Agustus & 1298 & 1140 & 87,8 & 1344 & 96,5 \\
\hline September & 1304 & 1193 & 91,5 & 1311 & 99,5 \\
\hline Oktober & 1308 & 1234 & 94,3 & 1364 & 95,7 \\
\hline November & 1209 & 1215 & 99,5 & 1324 & 90,5 \\
\hline
\end{tabular}

\begin{tabular}{lrrrrr}
\hline Desember & 1334 & 1340 & 99,6 & 1316 & 98,7 \\
\hline Hasil MAE & & & $\mathbf{7 6 , 2}$ & & $\mathbf{6 3 , 8}$ \\
\hline
\end{tabular}

Tabel 4. Hasil Peramalan dan MAE Aqua Galon 19 liter Tahun 2015

\begin{tabular}{lrrrrr}
\hline \multicolumn{1}{c}{ Bulan } & $\begin{array}{c}\text { Data } \\
\text { Aktual }\end{array}$ & \multicolumn{2}{c}{$\begin{array}{c}\text { Ramalan } \\
\text { Tahunan }\end{array}$} & \multicolumn{2}{c}{$\begin{array}{c}\text { Ramalan } \\
\text { Bulanan }\end{array}$} \\
\cline { 2 - 6 } & & Hasil & $\begin{array}{c}\text { Akurasi } \\
\text { (\%) }\end{array}$ & Hasil & $\begin{array}{c}\text { Akurasi } \\
\text { (\%) }\end{array}$ \\
\hline Januari & 1335 & 1338 & 99,8 & 1331 & 99,7 \\
\hline Februari & 1345 & 1392 & 96,5 & 1214 & 90,3 \\
\hline Maret & 1340 & 1385 & 96,6 & 1342 & 99,9 \\
\hline April & 1362 & 1394 & 97,7 & 1309 & 96,1 \\
\hline Mei & 1380 & 1363 & 98,8 & 1361 & 98,6 \\
\hline Juni & 1368 & 1356 & 99,1 & 1336 & 97,7 \\
\hline Juli & 1270 & 1270 & 100,0 & 1390 & 90,6 \\
\hline Agustus & 1290 & 1311 & 98,4 & 1362 & 94,4 \\
\hline September & 1312 & 1344 & 97,6 & 1307 & 99,6 \\
\hline Oktober & 1345 & 1378 & 97,5 & 1340 & 99,6 \\
\hline November & 1366 & 1307 & 95,7 & 1304 & 95,5 \\
\hline Desember & 1379 & 1482 & 92,5 & 1332 & 96,6 \\
\hline Hasil MAE & & & $\mathbf{3 3 , 7}$ & & $\mathbf{4 6}$ \\
\hline
\end{tabular}

Tabel 5. Hasil Peramalan dan MAE Aqua Galon 19 liter Tahun 2016

\begin{tabular}{lrlrrrr}
\hline \multicolumn{1}{c}{ Bulan } & $\begin{array}{c}\text { Data } \\
\text { Aktual }\end{array}$ & \multicolumn{2}{c}{$\begin{array}{c}\text { Ramalan } \\
\text { Tahunan }\end{array}$} & \multicolumn{2}{c}{ Ramalan Bulanan } \\
\cline { 2 - 7 } & & $\begin{array}{c}\text { Hasil } \\
\text { Akurasi } \\
\mathbf{( \% )}\end{array}$ & Hasil & $\begin{array}{c}\text { Akurasi } \\
\text { (\%) }\end{array}$ \\
\hline Januari & 1380 & 1421 & 97,0 & 1349 & 97,8 \\
\hline Februari & 1390 & 1518 & 90,8 & 1280 & 92,1 \\
\hline Maret & 1399 & 1516 & 91,6 & 1337 & 95,6 \\
\hline April & 1423 & 1537 & 92,0 & 1348 & 94,7 \\
\hline Mei & 1440 & 1530 & 93,8 & 1413 & 98,1 \\
\hline Juni & 1365 & 1512 & 89,2 & 1404 & 97,1 \\
\hline Juli & 1346 & 1405 & 95,6 & 1442 & 92,9 \\
\hline Agustus & 1387 & 1434 & 96,6 & 1423 & 97,4 \\
\hline September & 1404 & 1453 & 96,5 & 1369 & 97,5 \\
\hline Oktober & 1454 & 1482 & 98,1 & 1409 & 96,9 \\
\hline November & 1455 & 1456 & 99,9 & 1380 & 94,8 \\
\hline Desember & 1468 & 1532 & 95,6 & 1436 & 97,8 \\
\hline Hasil MAE & & & $\mathbf{7 3 , 7 5}$ & & $\mathbf{5 5 , 2 5}$ \\
\hline
\end{tabular}


Tabel 6. Hasil Peramalan dan MAE Aqua Galon 19 liter Tahun 2017

\begin{tabular}{lrrrrr}
\hline \multicolumn{1}{c}{ Bulan } & $\begin{array}{c}\text { Data } \\
\text { Aktual }\end{array}$ & \multicolumn{2}{c}{$\begin{array}{c}\text { Ramalan } \\
\text { Tahunan }\end{array}$} & \multicolumn{2}{c}{ Ramalan Bulanan } \\
\cline { 2 - 6 } & & $\begin{array}{c}\text { Hasil Akurasi } \\
\text { (\%) }\end{array}$ & Hasil & $\begin{array}{c}\text { Akurasi } \\
\text { (\%) }\end{array}$ \\
\hline Januari & 1502 & 1502 & 100,0 & 1455 & 96,9 \\
\hline Februari & 1520 & 1525 & 99,7 & 1343 & 88,4 \\
\hline Maret & 1547 & 1552 & 99,7 & 1498 & 96,8 \\
\hline April & 1577 & 1590 & 99,2 & 1486 & 94,2 \\
\hline Mei & 1591 & 1619 & 98,2 & 1577 & 99,1 \\
\hline Juni & 1551 & 1571 & 98,7 & 1572 & 98,6 \\
\hline Juli & 1533 & 1517 & 99,0 & 1623 & 94,1 \\
\hline Agustus & 1564 & 1555 & 99,4 & 1610 & 97,1 \\
\hline September & 1573 & 1572 & 99,9 & 1559 & 99,1 \\
\hline Oktober & 1580 & 1612 & 98,0 & 1606 & 98,4 \\
\hline November & 1603 & 1620 & 98,9 & 1562 & 97,4 \\
\hline Desember & 1623 & 1631 & 99,5 & 1612 & 99,3 \\
\hline Hasil MAE & & & $\mathbf{1 2 . 8}$ & & $\mathbf{5 2 , 2 5}$ \\
\hline
\end{tabular}

Tabel 7. Hasil Peramalan dan MAE Aqua Galon 19 liter Tahun 2018

\begin{tabular}{lrrrrr}
\hline \multicolumn{1}{c}{ Bulan } & $\begin{array}{c}\text { Data } \\
\text { Aktual }\end{array}$ & \multicolumn{2}{c}{$\begin{array}{c}\text { Ramalan } \\
\text { Tahunan }\end{array}$} & \multicolumn{2}{c}{ Ramalan Bulanan } \\
\cline { 2 - 6 } & & $\begin{array}{c}\text { Hasil } \\
\text { Akurasi } \\
\mathbf{( \% )}\end{array}$ & Hasil & $\begin{array}{c}\text { Akurasi } \\
\mathbf{( \% )}\end{array}$ \\
\hline Januari & 1605 & 1615 & 99,4 & 1619 & 99,1 \\
\hline Februari & 1619 & 1619 & 100,0 & 1479 & 91,4 \\
\hline Maret & 1639 & 1645 & 99,6 & 1612 & 98,4 \\
\hline April & 1660 & 1676 & 99,0 & 1594 & 96,0 \\
\hline Mei & 1604 & 1712 & 93,3 & 1645 & 97,4 \\
\hline Juni & 1637 & 1665 & 98,3 & 1619 & 98,9 \\
\hline Juli & 1640 & 1654 & 99,1 & 1652 & 99,3 \\
\hline Agustus & 1641 & 1704 & 96,2 & 1660 & 98,8 \\
\hline September & 1650 & 1726 & 95,4 & 1620 & 98,2 \\
\hline Oktober & 1639 & 1754 & 93,0 & 1658 & 98,8 \\
\hline November & 1605 & 1615 & 99,4 & 1619 & 99,1 \\
\hline Desember & 1619 & 1619 & 100,0 & 1479 & 91,4 \\
\hline Hasil MAE & & & $\mathbf{4 3 , 6}$ & & $\mathbf{3 8 , 6}$ \\
\hline
\end{tabular}

Berdasarkan perbandingan hasil peramalan periode tahunan dan bulanan (Tabel 2 sampai Tabel 7) dapat dilihat bahwa rata-rata peramalan periode bulanan memberikan nilai MAE lebih kecil dibandingkan peramalan periode tahunan. Walaupun Tabel 8 menunjukkan bahwa akurasi hasil peramalan terendah dan tertinggi dari periode tahunan lebih baik dari akurasi hasil peramalan periode bulanan, namun kalau dilihat lebih detail pada Tabel 2 sampai Tabel 7, terlihat akurasi peramalan periode bulanan lebih baik dari periode tahunan. Jadi dapat disimpulkan bahwa peramalan periode bulanan lebih baik dari pada peramalan periode tahunan.

Tabel 8. Hasil Tingkat Akurasi Peramalan Tahunan dan Bulanan

\begin{tabular}{rrrrr}
\hline Tahun & \multicolumn{2}{c}{$\begin{array}{c}\text { Akurasi Ramalan } \\
\text { Tahunan (\%) }\end{array}$} & \multicolumn{2}{c}{$\begin{array}{c}\text { Akurasi Ramalan } \\
\text { Bulanan (\%) }\end{array}$} \\
\cline { 2 - 5 } Terendah & \multicolumn{1}{c}{ Tertinggi } & Terendah & Tertinggi \\
\hline 2013 & 68,24 & 94,78 & 87,90 & 99,70 \\
\hline 2014 & 87,83 & 99,55 & 83,03 & 99,68 \\
\hline 2015 & 92,53 & 100,00 & 90,55 & 99,85 \\
\hline 2016 & 89,23 & 99,93 & 92,09 & 98,13 \\
\hline 2017 & 97,97 & 100,00 & 88,36 & 99,32 \\
\hline 2018 & 92,98 & 100,00 & 91,35 & 99,27 \\
\hline
\end{tabular}

Untuk mempermudah pengguna sistem membaca hasil peramalan maka sistem peramalan yang dibuat dilengkapi dengan laporan dalam bentuk grafik. Rekomendasi jumlah pembelian produk dapat dilihat pada sistem saat akan melakukan pemesanan ke supplier, sehingga hasil rekomendasi ini dapat dijadikan bahan pertimbangan dalam pengambilan keputusan jumlah pembelian produk. Pada rekomendasi pembelian juga dicantumkan detail posisi stok saat ini yang ditampilkan dalam bentuk tabel. Contoh hasil peramalan jumlah penjualan barang dan contoh rekomendasi jumlah pembelian barang dapat dilihat pada Gambar 2 dan 3.

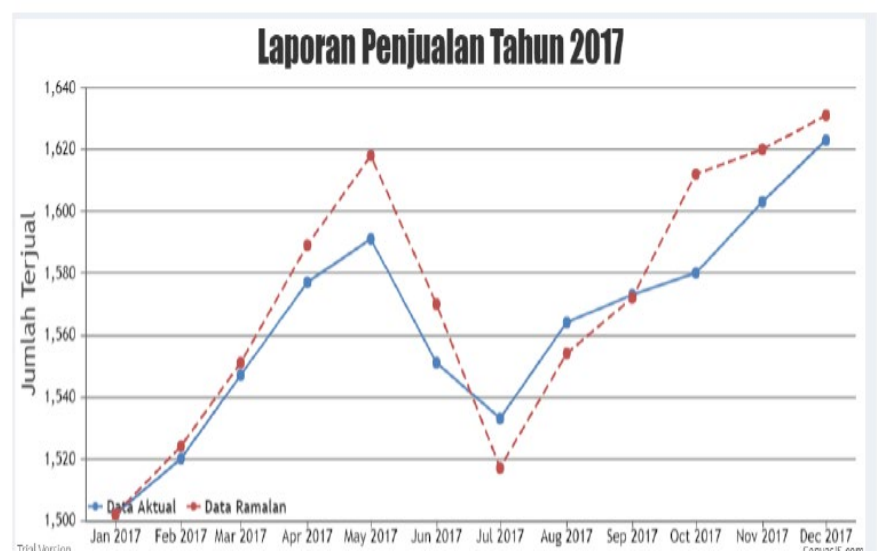

Gambar 2. Contoh Grafik Hasil Peramalan Permintaan Barang Dibandingkan Data Aktual 


\section{REFERENSI}

[1] Sugiarto \& Harijono. (2000). Peramalan Bisnis. Jakarta: PT. Gramedia Pustaka Utama.

[2] Dagum E.B. (2010). Time Series Modeling and Decomposition. Jurnal Statistika, Vol. 70 No. 4, pp. 433-457. ISSN 1973-2201.

[3] Kendek, O.J., Prang, J.D. \& Paendong, M. (2014). Prediksi Jumlah Pengunjung Perpustakaan Universitas Sam Ratulangi Manado Menggunakan Metode Dekomposisi. Jurnal de CARTESIAN, Vol. 3, No. 1, pp. 73-80.

[4] Wahyuni, S., Helma \& Amalita, N. (2014). Peramalan Kebutuhan Energi Jual pada PT Perusahaan Listrik Negara (PLN) Cabang Bukittinggi dengan Menggunakan Metode Dekomposisi Sensus II. Journal of Mathematics, Vol. 1, No. 1. ISSN: 977235516589.

[5] Sukiyono, K. \& Rosdiana (2018). Pendugaan Model Peramalan Harga Beras pada Tingkat Grosir. Jurnal Agrisep, Vol. 17, No. 1, pp. 23-30.

[6] Makridakis, S., Wheelwright, S.C., \& McGEE V.E. (1999). Metode dan Aplikasi Peramalan (Edisi 2). Jakarta: Erlangga.

Sistem peramalan yang dibuat dapat membantu untuk memperkirakan jumlah barang yang seharusnya dipesan ke suplier di periode mendatang. Hal ini sangat membantu pemilik perusahaan dalam proses mengontrol stok sehingga stok barang yang ada tidak berlebihan di dalam gudang dan permintaan pelanggan dapat dipenuhi.
[7] Ajeng, S., (2011). Peramalan Penjualan Untuk Perancanaan Pengadaan Persediaan Buah Durian Di Rumah Durian Harum Bintaro Jakarta [Skripsi]. Jakarta: Fakultas Sains dan Teknologi Universitas Islam Negeri Syarif Hidayatullah. 